\title{
The Actual Application of Flipped Classroom Mode in Cost Accounting Practical Training
}

\author{
Tangmei Yuan ${ }^{1, a^{*}}$ \\ ${ }^{1}$ Department of Accounting, Linyi University, Shandong, China \\ ayyytm@126.coml
}

Keywords: Flipped classroom; Cost accounting practical training; Teaching innovation

\begin{abstract}
Cost accounting course consists of the theory teaching and practice teaching. Now, the cost accounting teaching hard to meet the needs of cost accounting jobs due to the compression of total teaching hours and lack of practical input. This paper discuss how to design and implement cost accounting practice training according to flipped classroom concept with the purpose of providing experience for cost accounting practice teaching reform. After a semester of practice, we confirmed that the flipped classroom model contributed to cost accounting practical training: the improvement of student interest in the course, the improvement of students' ability of autonomous learning so that students practical material have been done more perfect, the improvement of student exploring spirit, and dare to express their ideas on their own initiative, the enrichment of teaching and learning processes, aspects related to the role change of professors and students.
\end{abstract}

\section{Introduction}

Educators know all too well the persistent challenge of how best to use technology when helping students learn. With the increased availability of the internet and computer applications over the past 20 years, college and university professors have strengthened their commitment to use computer technology to enhance classroom learning. As with any educational tool, there are many strategies for using computer technology. One such strategy relies on technology to introduce students to course content outside of the classroom so that students can engage that content at a deeper level inside the classroom. Because this way of structuring the classroom turns around the more traditional pattern of introducing students to content inside the classroom and assigning homework to engage content at a deeper level outside the classroom, it is referred to as the flipped classroom.

\section{Origin and Development of Flipped Classroom}

Perhaps the flipped classroom design has been around for decades as teachers have required students to read course material before coming to class and engage the concepts at a deeper level during class. In addition, some could say that teachers who used educational television or computer-assisted instruction during the past 40 years of educational technology use were flipping their classrooms. Indeed, the flipped classroom has arisen within a broader 15-year pedagogical development in higher education that has seen an increased mixture of face-to-face classroom experiences with online learning experiences from the distributed learning tradition. This mixture of methods has garnered the name blended learning[1].

Jonathan Bergmann and Aaron Sams developed the model in 2006 in the Secondary School of Woodland Park, Colorado, where both worked as teachers. The concept has evolved since, and it has given way to a methodology that goes beyond the mere substitution of the classic lecture for a video[2]. The flipped classroom is based on a model that reorganizes the time in and outside the classroom. The model is part of a wider pedagogical movement that overlaps with blended learning, learning based on research, and with those approaches that promote active participation of students and flexibility within educational processes. 


\section{The Advantage of Flipped Classroom}

Embody the Student Centered. The flipped classroom paradigm positions students in the center of the process, with models that stimulate their curiosity, creativity, abilities, teamwork, and knowledge acquired outside the classroom. Additionally, the resources have been already created and can be found online. All it needs is for the professors to make the materials available to students.

Once that is done, students are expected to work, analyze, and interpret the material, and even improve it. In a nutshell, this new paradigm aims to change the role of the professor, and turn the professor into a figure that spends less time explaining and more time stimulating, advising, and supporting students.

Students Learn More Effectively. The foundation of the inverted classroom is based upon the essential concept that students learn more effectively if they become actively engaged with the material. This is now a well-developed tenet of good undergraduate education, which has been demonstrated through numerous studies over the past 50 years. It is also well understood that the traditional 50 minute one-way lecturing format is a poor method of teaching due to students' finite attention capabilities. This new approach provides students with the necessary introduction to the course material through shorter 10 to 15 minute videos, and gives them the opportunity to learn the material more deeply through supervised active exercises.

Creates a More Inclusive Learning Environment. Another advantage of this new teaching method is that it creates a more inclusive learning environment, one which reaches students of different learning styles and diverse cultural backgrounds. Through the availability of the introductory "lesson" videos and the follow-up "lecture" videos, students can watch the videos at their own pace and review them as needed. In addition, the variety of learning experiences which can now be used in the face-to-face time along with the different types of supporting features, allows for a wider array of learning domains to be reached. Indeed, adapting one's teaching approach to meet the needs of a wide range of learning styles leads to a better quality educational experience for all students.

Students Could Develop Critical and Independent Thinking. The flipped classroom offers more opportunities for students to develop critical and independent thinking, and for students to enhance their own learning processes by interacting collaboratively with peers. Further, professors give more flexibility and freedom to students so they can learn from activities specially designed to enhance their problem-solving skills.

Suitable for Practical Training Courses. According to the tracking and evaluation to flipped classroom, most literature indicate that flipped classroom don't have more advantages on teaching efficiency of the principle and concept knowledge than traditional teaching. Flipped classroom is suitable for experiment, practice, application classes. Some scholars study found through action, flipped classroom teaching model in the application of the university experimental teaching can change the traditional experiment teaching, the teacher tells the students listen, simple practice form of teaching, can effectively improve the students' learning enthusiasm and learning efficiency, and improve students to autonomous learning, and experiment reflection, and enhance the ability to solve problem.

\section{Designing and Implementation of the Cost Accounting Practice Training Flipped Classroom}

Flipped classroom don't have more advantages than traditional teaching on teaching efficiency of the principle and concept knowledge, and sometimes it need more class time to organize classroom teaching activities, it is easy to lose the classroom teaching schedule, and will lower the efficiency of teaching. Flipped classroom also requires college students should have higher ability of self-management and autonomous learning. Therefore, we only had the practice part of cost accounting designed flipped classroom teaching and implementation in this semester.

When doing cost accounting training courses, students have learned basic accounting, intermediate financial accounting, cost accounting related content. When students enter the laboratory simulation training, the teacher should be completely let them go, Let the students begin to do, and give them the opportunity to make mistakes, and then urge them to correct correction. But that doesn't mean the 
teacher can entirely no matter, only put students in the practice room. Good classroom teachers need to design each teaching task, reasonable arrangement good student training process, and discuss with the student to carry on summary.

Research has shown that, for blended learning environments to be successful, it is important to structure the face-to-face and the online portions of the learning experience so that they coherently support one another to help students to achieve the learning goals for the course[3]. When the online and face-to-face portions of the learning experience are not carefully aligned, studies have shown that technology can become a barrier for students as they choose how fully they will invest in the learning goals of the classroom[4].

Other research has shown that successful blended learning occurs when teachers go beyond just replacing the lecture with an online learning event. Interactive technologies make it possible for educators to qualitatively reconceptualise the teaching and learning dynamic. By augmenting the fast paced interaction and dialogue that happens in the face-to-face setting with an online learning environment that gives students space to take in new ideas, deliberate and carefully express their thoughts on the subject, teachers are able to create learning communities that are more connected and more stable than we have seen in the past[5]. So, based on flipped class concept, the design of cost accounting practice teaching is as follows.

Divide the Knowledge Unit and Refinement the Granularity of Every Knowledge Unit. The first key element that ensures the success of the process is the development of a well-organized teaching plan, which specifies the activities that will be carried out, as well as the resources and contents that will be consulted [6]. In this way, the student will have a clear idea of the work schedule; will be able to locate the material needed on the resources provided; and, will know when he/she is required to do the different activities.

In the flipped classroom teaching mode, teachers are no longer need to speak new lesson content before cost accounting practice training, only need to put the task of cost accounting training courses subdivided into several units. A detailed and explicit plan will result in a decrease of the student's anxiety and in an increase of his/her confidence regarding the working methodology (shown in table 1) .

Then, we refinement of knowledge unit as far as possible to the grain size, and give each unit micro video, each knowledge unit will let students know clearly specific achieving goals. Traditional teaching video general knowledge is based on the content of a class as a unit to carry on the teaching, time is more than 45 minutes. Due to the video contains images, text, sound, the message is very rich. If time is too long the student will be difficult to digest. In flipped classroom, is different in handling of knowledge unit, to further refine training content for a number of points according to the practical steps, using a "little video" to explain each knowledge point, and equipped with corresponding specific exercises to consolidate, these micro video length, usually in 5-10 minutes, not more than 15 minutes.

Preparation Before Class. (1)Teacher. In an inverted classroom, typical outside class time, lectures are delivered over some other medium such as video on-demand. So, after the training content is divided into several units, we made the micro video in advance according to each unit of the teaching goal. In the case of the preparation of proof of charge to an account. First, the teacher select a record screen software, Then in blank PowerPoint presentations for electronic whiteboards, The interpretation of the problem of the process step by step to present on the PPT presentations Based on the students' cognitive regularity and internal logic of knowledge, At the same time with pronunciation. Make a mark for error-prone place. Such recording teaching video, in addition to teaching contents and phonetic explanation, no other redundant information; more conducive to focus students' attention, so as to improve the efficiency of autonomous learning before class compared with the traditional teaching video presentation. Secondly, according to the schedule, it will be recorded each micro video uploaded to the network platform as planned, and inform the student training work time according to the row, clear each training unit training task, let the students know what to do in this link.(2)Students. Outside class time, the responsibility is that lets the students carry out part of the assessed activities outside the classroom without the direct guidance of the professor. Organizing the contents in different units according to the program in table 1. Outside class time, lectures are delivered over some other medium such as video on-demand. Students are with a faculty member and actively engaged in learning activities. Developing 
multiple choice question activities that offer opportunity for self-assessment, while that limiting or approving the progression of the student in the course depending on performance. Suggesting comprehension activities assessed by the teacher. Establishing online forums that function as collaborative spaces of common reflection, where students will share resources, ask and solve questions, or analyze topics at hand related to the course. the student builds his/her knowledge interacting and cooperating with peers in the online space.

Table 1 Cost accounting training course knowledge unit grain size refinement

\begin{tabular}{|c|c|c|}
\hline knowledge unit & work task & $\begin{array}{l}\text { Feedback and } \\
\text { communication }\end{array}$ \\
\hline $\begin{array}{l}\text { Prepare accounts and Posting } \\
\text { at first }\end{array}$ & $\begin{array}{l}\text { According to the needs, set up various subsidiary } \\
\text { accounts, beginning balance of the input }\end{array}$ & \multirow{8}{*}{$\begin{array}{l}\text { The students } \\
\text { finish each unit } \\
\text { task within the } \\
\text { allotted time, } \\
\text { and shown task } \\
\text { work content } \\
\text { after Each unit. } \\
\text { Every groups } \\
\text { exchange } \\
\text { experience, } \\
\text { feedback } \\
\text { problems and } \\
\text { solutions. }\end{array}$} \\
\hline $\begin{array}{l}\text { Prepare a list of the elements } \\
\text { of cost allocation }\end{array}$ & $\begin{array}{l}\text { Prepare a list of the various elements of cost } \\
\text { allocation }\end{array}$ & \\
\hline $\begin{array}{l}\text { Preparation of accounting } \\
\text { documents }\end{array}$ & $\begin{array}{l}\text { preparation of proof of charge to an account } \\
\text { according to the original documents }\end{array}$ & \\
\hline $\begin{array}{l}\text { Registration of subsidiary } \\
\text { ledger }\end{array}$ & $\begin{array}{l}\text { Register all kinds of subsidiary ledger according } \\
\text { to proof of charge to an account }\end{array}$ & \\
\hline $\begin{array}{l}\text { Prepare a list of the auxiliary } \\
\text { production cost allocation }\end{array}$ & $\begin{array}{l}\text { Prepare a list of the various auxiliary workshop } \\
\text { production cost allocation }\end{array}$ & \\
\hline $\begin{array}{l}\text { Prepare a list of the } \\
\text { manufacturing cost allocation }\end{array}$ & $\begin{array}{l}\text { Prepare a list of the various basic production } \\
\text { workshop of manufacturing cost allocation }\end{array}$ & \\
\hline $\begin{array}{l}\text { Compile product cost } \\
\text { calculation sheet, inbound and } \\
\text { outbound }\end{array}$ & $\begin{array}{l}\text { Compile workshop product cost calculation } \\
\text { sheet, calculate the cost of finished products, and } \\
\text { processing semi-finished products inbound and } \\
\text { outbound }\end{array}$ & \\
\hline Cost revivification & Overall process of calculating cost revivification & \\
\hline
\end{tabular}

In the case of the preparation of accounting documents. Students would be fill out the bookkeeping voucher by watching this unit of video in their spare time. In the training process, students can choose the appropriate time and place to watch the video and practical operation according to their own situation, can choose watch or not watch the video according to their need and training schedule. Students also can achieve interaction between teachers and students by using the network teaching platform, The purpose is to understand the problem thoroughly and finish the training topic in a timely manner.

Face-to-Face Classes_—Feedback, Communication and Demonstrate. An "inverted classroom" is a teaching environment that mixes the use of technology with hands-on activities. In an inverted classroom, typical in-class lecture time is replaced with laboratory and in-class activities. In-class active learning opportunities, including conceptual questions and peer instruction facilitated through a classroom-response system, group work exercises, and opportunities for individual work and consideration of the material at hand. Flipped classroom encourages students to gain the required base knowledge of a concept prior to class through short "mini-lecture" videos or other preparatory exercises. The great potential for this approach is that it provides instructors with the opportunity to reimagine and redesign the in-class experience to create a more active learning environment.

In face-to-face classes, the professor can devote the first part of the class to reviewing the contents of the course, which can serve as an introduction to the practical work that students will carry out during the class. For this practical work, the students will be divided into small groups and the professor will help each group to carry out the activity. Upon completion of the activity, each group shares what has been learnt with the rest of the class, and then, the students discuss the solutions and results proposed by each group. The activity can end with a reflection about the competencies that the student developed during the activity. 
In the case of the preparation of accounting documents. First, the students will be divided into small groups, group leader check his group members completion of tasks in this unit, And select complete good students to demonstrate in the class. Second, groups to find out the wrong credentials, Discuss each other between the students, then teacher do inductive summary aimed at these problems, and strengthen remind. When necessary, the collective can watch the video again, Student control video to find out their respective problems and to find out the reasons. This will give students a deep impression.

Students Generalization and Summarization of Themselves. This is a very important link that students must be find out the problems of their own group in the discussion and work experiences that is worth popularizing in the other groups. Students run through theoretical knowledge had learned before through discussion, realizes the theory instruction practice once again, At the same time also can achieve the objectives of promotion theory by practice.

Overall Assessment. Finally, regarding the assessment process, we aim to develop a type of continuous assessment throughout the whole process. The goal is to achieve a type of assessment that advances in juxtaposition with the learning process, which raises relevant questions among students while also encouraging them to learn from their mistakes. After feedback, communication, demonstrate, and Students summary, we would to be the teacher assessment students and evaluation between students. On the one hand, teacher conducting a reasonable evaluation to student's work, it is affirmed students labor, It is the incentive to students, and A requirement of course examination, then students will have more full of enthusiasm to finish the training work; On the other hand, evaluation between students, evaluation among team members mainly in order to better supervise each student to complete the training task, and promote group to enhance team cohesion.

The intention of the project is to study the effect of using podcasting in an inverted classroom upon the ability to meet course learning outcomes, faculty preparation overhead, and student effort. One of the difficulties in gauging real cause and effect is that there is no available control or other experience in which to measure faculty overhead or student effort other than through self-reporting. As a result, our eventual focus will be on perceptions of students through surveys as well as measurement of coverage of topics. Specifically, it is expected that one of the outcomes will be that more topics can be covered while not sacrificing student learning (and student perception of learning).

\section{Implementation Results of Cost Accounting Practice Turning Flipped Classroom}

Cultivate the Students' Ability of Autonomous Learning, Students Practical Material have been Done More Perfect. It's worth noting that the improvement of student interest in the course, the improvement of students' ability of autonomous learning so that students practical material have been done more perfect. Compared with past students training materials, the students practical training material have been completed specification and comprehensive, smooth writing and clear, there are few large altered. During training, students could have a choice of doing personalized learning, cultivate their autonomous learning, cooperative learning, and to analyze problems independently.

Cultivate the Students' Exploring Spirit, and Dare to Express Their Ideas Initiative. The flipped classroom model does improve the academic performance of students as well as their engagement with the learning process. The student ceases to be a passive element and develops key competencies such as: selection of information, teamwork, critical thinking, and self-management and self-assessment of the learning process.

Flip the class can change the whole process of interaction between teachers and students, improve students' independent initiative thinking and problem solving skills. Micro video problems proposed in the innovative, Can better stimulate students' thinking, can improve the initiative and enthusiasm of students to participate in. after Flip class, students dare to take the initiative to speak in class, actively express their ideas, the classroom atmosphere more harmonious. Teachers can enrich and develop students' opinion, make all students accepted to a more complete and clear information.

Changed the Teacher's Role. The teacher mediates, offers support, and guides. That is, The flipped classroom model gives the teacher more flexibility to offer learning opportunities based on problem-solving activities, which aim to give confidence and orientation to the student. This type of 
innovation requires the professors to rethink the way they organize the class and the classroom. The professors need to: move away from the traditional role of the professor by reducing the time for explanations and increase collaborative spaces by developing projects in the classroom, planning and preparing activities in advance, and expanding the formative space through the micro video, online activities, shared resources, etcetera, among others. This is also a model that integrates the micro videos in the teaching-learning process, helps to organize knowledge collectively, puts the students in the center of the process, and teaches basic competencies.

\section{Conclusions}

The flipped classroom model contributed to cost accounting practical training: the improvement of student interest in the course, the improvement of students' ability of autonomous learning so that students practical material have been done more perfect, the improvement of student exploring spirit, and dare to express their ideas on their own initiative, the enrichment of teaching and learning processes, aspects related to the role change of professors and students. It is successful that cost accounting practice training design and implement according to flipped classroom concept. It could save time and solve the problem of the compression of total teaching hours and lack of practical input. So it can provide experience for cost accounting practice teaching reform.

\section{References}

[1] R. Donnelly, Harmonizing technology with interaction in blended problem-based learning. Computers \& Education, 54(2010) 350-359.

[2] A. L. Carballo, Reflections on Blended Learning. El Guiniguada, 23(2014) 63-70.

[3] P. Ginns, R. Ellis, and Quality in blended learning: Exploring the relationships between on-line and face-to-face teaching and learning. Internet and Higher Education, 10 (2007) 53-64.

[4] J. P. Buerck, T. Malmstrom, E. Peppers, Learning environments and learning styles: Nontraditional student enrollment and success in an internet-based versus a lecture-based computer science course. Learning Environments Research, 6(2003) 137-155.

[5] D. R. Garrison, H. Kanuka, Blended learning: Uncovering its transformative potential in higher education. Internet and Higher Education, 7(2) (2004) 95-105.

[6] Flores, to plan a flipped classroom. Escuela, monographic, (2015) 7-8. 